\title{
Large Scale Simulation of Coke and Iron Ore Particle Motions and Air Flow in Actual Blast Furnace
}

\author{
Shinichi YUU, ${ }^{1)}$ Toshihiko UMEKAGE ${ }^{2)}$ Shinroku MATSUZAKI, ${ }^{3)}$ Masatomo KADOWAKI ${ }^{3)}$ \\ and Kazuya KUNITOMO ${ }^{31}$
}

1) Ootake R. and D. Consulting Office, 1-17-27-508 Ootake, Higashi-ku, Fukuoka 811-0322 Japan.

2) Department of Mechanical Engineering, Graduate School of Engineering, Kyushu Institute of Technology, 1-1 Sensuicho, Tobata-ku, Kitakyushu 804-8550 Japan. 3) Engineering Research Center, Nippon Steel Corporation, 20-1 Shintomi,

Futtsu 293-8511 Japan.

(Received on October 22, 2009; accepted on January 23, 2010)

\begin{abstract}
The computational program for the particle and the air flows in an actual blast furnace using Distinct Element Method (DEM) for the coke and the iron ore particles of which number was about 16 million and the Finite Difference Method of which computational cell number was about 3 million for the numerical analysis of Navier-Stokes equations with the interaction terms between the air and the particles has been developed. The motions of coke and iron ore particles and the air flow in the blast furnace have been simulated using this program. The computational domain in the tangential direction was $1 / 4$, which was 90 degree of the region of the horizontal plane and in which 10 tuyeres were arranged, of the actual blast furnace. The simulation results showed that the model softening melting cohesive zones, which were formed by the model that $50 \%$ volume of the ore particle melted and the diameter $D_{p}$ reduced to $0.794 D_{p}$ by melting the particle surface at the $1200^{\circ} \mathrm{C}$ line and the residue of the ore particle melted down completely at the $1400^{\circ} \mathrm{C}$ line, largely affected the air and the coke particle flows and caused the non-homogeneous and unstable flows. The air was divided into two flows at the softening melting cohesive zones. The one was the flow with the slope angle nearly $45^{\circ}$ from the horizontal toward the furnace wall in the central region and the other is vertically upward flow in the region near the furnace wall. The coke and ore particle velocities on the wide region of the furnace wall became very low. These nearly quiescent solid particle layers might cause the scaffold of the solid particle bed on the furnace wall. The results also showed that the interaction between tuyeres affected the shape and the stability of the raceway and influenced the particle and the air flows in the wide region on the raceway. Hereafter we will continue to calculate the air and the particle motions, and present the various unstable motions which would bring about an extraordinary event in the actual blast furnace.
\end{abstract}

KEY WORDS: numerical simulation; distinct element method; finite difference method; Navier-Stokes equation; blast furnace; softening melting cohesive zone; raceway; coke; iron ore.

\section{Introduction}

Numerical simulation of particle and gas flows in a blast furnace is one of the most interesting research topics in many kinds of technology, particularly the iron steel engineering. Yamaoka and Nakano ${ }^{1)}$ calculated the particle motion in the cold model blast furnace of which width is $0.5 \mathrm{~m}$ and height is $1.0 \mathrm{~m}$ using Distinct Element Method (DEM). They showed the effect of the tuyere diameter, the tuyere length and the bosh angle on the gas and the particle flows. $\mathrm{Xu}$ et $\mathrm{al}^{2}{ }^{2)}$ studied numerically the gas and particle flows in the bed with $0.3 \mathrm{~m}$ width, $1.0 \mathrm{~m}$ height and the thickness equal to the particle diameter $0.004 \mathrm{~m}$ using a continuum model for gas phase and discrete model for solid phase. They presented the dependency of raceway and fluidization on gas velocity by the size and the shape of the mobile zone, flow patterns and particle forces. Zhang et al. ${ }^{3)}$ simulated numerically particle flow in a two dimensional cold model blast furnace with $0.43 \mathrm{~m}$ width and $0.8 \mathrm{~m}$ height using the continuum model for both gas and solid phases. The results showed that the mass loss strongly affected the solid flow pattern and deadman profile. Increasing the solid consumption rate increased the solid velocity and decreased the deadman size. Takahashi et al. $^{4)}$ calculated the stress distribution on the deadman surface by extending Walters theory ${ }^{5,6)}$ assuming deadman to be a conical body. Their results indicated that the floating mode depended on the horizontal profile of vertical load. Nouchi et al. ${ }^{7)}$ presented the gas-solid flow in a water model using DEM. The results showed that the flow pattern and stagnant zone profile were affected by the level of liquid and the position of discharging hole. Nogami et $a l{ }^{8)}$ calculated the gas and particle flows in a small scale model blast furnace using DEM. The heat exchange and the chemical reactions were considered. Their results describe that the blast temperature and the blast compositions could control the raceway shape, the 
size and the gas temperature. All of these studies are for a small scale model blast furnace. Results and findings for an actual blast furnace would be necessary.

Unstable flows in an actual blast furnace reduce the iron manufacturing efficiency, then $\mathrm{CO}_{2}$ discharge from the furnace increases. The objective of our study including our future work is to present various flows in the actual blast furnace and elucidate the unstable phenomena which cause inefficiency manufacturing operation. In this study we have calculated simultaneously the motion of solid particles which were coke and iron ore and the air flow in the actual blast furnace. The flow of solid particles, the air flow, the softening melting cohesive zones and the raceway are presented.

Calculated results show the formation of the model softening melting cohesive zone, the velocity distributions of solid particles and the air, the packing ratio distributions and the interaction between raceways. The results describe that these dynamical characteristics in the blast furnace are unstable and fluctuate, and suggest that an unusual phenomenon would happen under some conditions.

\section{Computational Procedure}

\subsection{Gas Phase Calculation}

The governing equations for the gas phase are the threedimensional Navier-Stokes equations with interaction terms between the gas and particles, and the fluid continuity equation. In the present simulation the air was used for the gas. The non-dimensional forms are as follows:

$$
\begin{aligned}
& \varepsilon \frac{\partial \mathbf{u}}{\partial t}+(\varepsilon \mathbf{u} \cdot \nabla \mathbf{u}) \\
& =-\varepsilon \nabla p+\frac{\varepsilon}{\operatorname{Re}}\left[\nabla^{2} \mathbf{u}+\frac{1}{3} \nabla(\nabla \cdot \mathbf{u})\right]-\mathbf{S t}-\mathbf{S t}_{\mathbf{L}} \ldots(1) \\
& \frac{\partial \varepsilon}{\partial t}+\varepsilon \nabla \cdot \mathbf{u}=0 \ldots \ldots \ldots \ldots \ldots \ldots \ldots \ldots \ldots \ldots \ldots \ldots \ldots \ldots
\end{aligned}
$$

In the above equations the characteristic velocity $U_{0}$ $(=250 \mathrm{~m} / \mathrm{s})$ which is the air velocity at the tuyere outlet, the characteristic length $D(=7.35 \mathrm{~m})$ which is the radius of the blast furnace at the tuyere section and the characteristic time $D / U_{0}$ are used.

St and $\mathbf{S t}_{\mathbf{L}}$ in the above equations are the interaction terms of the drag and the lift forces between the air and the particles. Motions of the air and the particles linked through these interaction terms. Substitution of the drag coefficient into the equation of the drag force gives the equation for St. We used Schiller and Naumanns ${ }^{9}$ experimental drag coefficient, which is applicable to flows of the particle Reynolds number $\operatorname{Re}_{p}<1000$.

$$
\begin{array}{r}
\mathbf{S t}=\frac{3 \pi \mu D_{p} N D\left(1+0.15 \operatorname{Re}_{p}^{0.687}\right)}{U_{0} \rho}\left(\mathbf{u}-\mathbf{u}_{\mathbf{p}}\right) \xi(\varepsilon) \\
\left(0 \leq \mathrm{Re}_{p} \leq 1000\right)
\end{array}
$$

When $\operatorname{Re}_{p}$ is larger than 1000 , Newton's drag coefficient gives the following equation.

$$
\mathbf{S t}=0.055 \pi D_{p}^{2} N D\left(\mathbf{u}-\mathbf{u}_{\mathbf{p}}\right)^{2} \xi(\varepsilon) \quad\left(1000<\operatorname{Re}_{p}\right) .
$$

The correction factor $\xi(\varepsilon)$ in the above equations describes the effect of neighboring particles on the drag force. We used the experimental equation presented by Umekage and Yuu. ${ }^{10)}$

$$
\xi(\varepsilon)=3.8-\frac{5.4}{\varepsilon}+\frac{2.6}{\varepsilon^{2}}
$$

For the lift force term $\mathbf{S t}_{\mathbf{L}}$, we used the following equations.

$$
\mathbf{S t}_{\mathbf{L}}=\frac{\pi}{16}\left(\frac{C_{L}}{\Omega^{*}}\right) D_{p}^{3} N\left(\mathbf{u}-\mathbf{u}_{\mathbf{p}}\right) \times\left(\frac{1}{2} \nabla \times \mathbf{u}-\boldsymbol{\omega}_{\mathbf{p}}\right) \xi_{L}(\varepsilon)
$$

where we used the equations ${ }^{11)}$ obtained by formulating Kurose and Komoris ${ }^{12)}$ calculated data for the lift coefficient $C_{L}$. We used the approximate equation of $\xi_{L}(\varepsilon)=\xi(\varepsilon)$ for the correction factor for the lift force.

In case of $\operatorname{Re}_{p \omega}>1000$, Eq. (7) for Magnus lift force is applicable.

$$
\mathbf{S t}_{\mathbf{L}}=\frac{\pi}{32} D_{p}^{3} N\left(\mathbf{u}-\mathbf{u}_{\mathbf{p}}\right) \times\left(\frac{1}{2} \nabla \times \mathbf{u}-\boldsymbol{\omega}_{\mathbf{p}}\right) \xi_{L}(\varepsilon) .
$$

The following Poisson equation derived by taking the divergence of Navier-Stokes equations was solved by the relaxation method. ${ }^{13)}$

$$
\begin{aligned}
\varepsilon \nabla^{2} p= & -\nabla \cdot\left(\varepsilon \frac{\partial \mathbf{u}}{\partial t}\right)-\varepsilon \nabla \cdot(\mathbf{u} \cdot \nabla \mathbf{u}) \\
& +\frac{\varepsilon}{\operatorname{Re}} \nabla \cdot\left[\nabla^{2} \mathbf{u}+\frac{1}{3} \nabla(\nabla \cdot \mathbf{u})\right]-\nabla \cdot \mathbf{S t}-\nabla \cdot \mathbf{S t}_{\mathbf{L}}
\end{aligned}
$$

We used the fourth order central difference scheme for the convection terms and the second order central difference scheme for other spatial derivative terms. The second order Runge-Kutter method is used for the time derivative terms.

\subsection{Particle Calculation}

The particle motions were calculated using DEM. ${ }^{11,14)}$ An elastic spring and a viscous dashpot between particles were introduced to calculate the force on a given particle by the contact with the other particles. In the shearing direction, a friction slider was also applied to calculate the slip at the contact point. In this study, the Hertz contact theory ${ }^{15)}$ was used to estimate the elastic spring constant. The equations for the particle motion are as follows,

$$
\begin{array}{r}
m_{p} \frac{d\left(\mathbf{U}_{\mathbf{p i}}\right)}{d T}=\sum_{\mathbf{j}}\left(\mathbf{F}_{\mathbf{i j}}+\mathbf{D}_{\mathbf{i j}}\right)+\mathbf{F}_{\mathbf{D i}}+\mathbf{F}_{\mathbf{L i}}+\mathbf{F}_{\mathbf{C i}}+\mathbf{F}_{\mathbf{R i}}+\mathbf{F}_{\mathbf{G i}} \\
I_{p} \frac{d\left(\mathbf{\Omega}_{\mathbf{p i}}\right)}{d T}=\sum_{\mathbf{j}}\left(\mathbf{M}_{\mathbf{i j}}+\mathbf{M}_{\mathbf{D i j}}\right)+\mathbf{M}_{\mathbf{F i}} \ldots \ldots \ldots \ldots \ldots \ldots \ldots \ldots \ldots \ldots \ldots \ldots \ldots \ldots \ldots \ldots \ldots \ldots \ldots \ldots \ldots \ldots \ldots \ldots \ldots \ldots
\end{array}
$$

The first terms of the right hand side in Eqs. (9) and (10) 
are the resultant contact force and the resultant contact moment among the reference particle $i$ and the contact particles $j . \mathbf{F}_{\mathbf{D i}}$ and $\mathbf{F}_{\mathbf{L i}}$ in Eq. (9) are the drag force and the lift force between the reference particle $i$ and the air. $\mathbf{F}_{\mathbf{D i}}$ and $\mathbf{F}_{\mathbf{L i}}$ are obtained using the dimensional forms of Eqs. (3), (4), (6) and (7) for the particle $i . \mathbf{F}_{\mathbf{C i}}$ and $\mathbf{F}_{\mathbf{R i}}$ in Eq. (9) are the cohesion force by the liquid bridge and the drag force which acts on approaching particles in the liquid film. $\mathbf{F}_{\mathbf{C i}}$ and $\mathbf{F}_{\mathbf{R i}}$ were calculated by the following Eqs. $(11)^{16)}$ and (12). ${ }^{17)}$

$$
\begin{aligned}
& F_{C}=\pi \gamma d \sin \alpha\left[\sin (\alpha+\Theta)+\frac{d}{4}\left(\frac{1}{R_{1}}-\frac{1}{R_{2}}\right) \sin \alpha\right] \\
& F_{R}=3 \pi \mu_{l} d u_{p n} \beta \\
& \beta=\frac{4}{3} \sinh \phi \sum_{n=1}^{\infty} \frac{n(n+1)}{(2 n-1)(2 n+3)} \\
& \times\left[\frac{2 \sinh (2 n+1) \phi+(2 n+1) \sinh 2 \phi}{4 \sinh ^{2}(n+1 / 2) \phi-(2 n+1)^{2} \sinh ^{2} \phi}-1\right], \\
& \phi=\cosh ^{-1} \frac{2 L}{d}
\end{aligned}
$$

$\mathbf{F}_{\mathbf{G i}}$ in Eq. (9) is the gravitational force of the particle $i$. Takagi $^{18)}$ gives the following equation for the fluid friction torque.

$$
\mathbf{M}_{\mathbf{F i}}=\frac{1}{2} M\left(\frac{D_{p}}{2}\right)^{5} \rho\left(\frac{1}{2} \nabla \times \mathbf{U}-\mathbf{\Omega}_{\mathbf{P i}}\right)\left(\frac{1}{2} \nabla \times \mathbf{U}-\mathbf{\Omega}_{\mathbf{P i}}\right)
$$

when

$$
\operatorname{Re}_{p \omega}<1, \quad M=16 \pi \operatorname{Re}_{p \omega}^{-1}
$$

and when

$$
1 \leq \operatorname{Re}_{p \omega}<10, \quad M=16 \pi \operatorname{Re}_{p \omega}^{-1}+0.0418
$$

Yuu et al. ${ }^{11)}$ present the detail of the similar computational procedure of DEM in the journal. See the paper of Ref. 11) for the detail.

\subsection{Computational Domain and Conditions}

Figure 1(a) shows the computational domain in $R-Z$ plane and the boundary conditions. Table 1 indicates the calculation conditions. The height and the radius of the computational domain were almost the same as those of Nippon Steel Co., Ooita No.1 BF as shown in Fig. 1(a). The computational domain in the tangential direction was $1 / 4$, which was 90 degree of the region of the horizontal plane of the actual blast furnace and in which 10 tuyeres were installed as shown in Fig. 1(b). Nozzle direction used in this simulation was 7 degree downward. The particle number calculated and other computational conditions are shown in Table 1. Other boundary conditions are shown in Fig. 1(a).

Coke burns and disappears in a raceway in a blast furnace. To represent this fact, we have erased 6-9 coke particles per one time step and per one tuyere in the spherical region in $2 \mathrm{~m}$ diameter in front of a tuyere outlet including the raceway as shown in Fig. 2. The relative velocity between coke particles and air promotes the combustion of (a)

\begin{tabular}{|c|c|}
\hline Time step & $\Delta \mathrm{T}=1.6 \times 10^{-4} \mathrm{~s}$ \\
\hline Number of computational cells & $57(\mathrm{R}) \times 140(\theta) \times 348(\mathrm{Z})=2,777,040$ \\
\hline $\begin{array}{l}\text { Computational cell size } \\
\text { for air Flow }\end{array}$ & $\Delta \mathrm{R}=147.0 \mathrm{~mm}, \Delta \theta=1.122 \times 10^{-2} \mathrm{rad}, \Delta Z=80.0 \mathrm{~mm}$ \\
\hline Tuyere outlet air velocity & $\mathrm{U}_{0}=250 \mathrm{~m} / \mathrm{s}$ \\
\hline Mean particle diameter & $\begin{array}{l}\text { Coke : } 57 \mathrm{~mm} \\
\text { Ore }: 45 \mathrm{~mm} \\
\text { Wall particle }: 50.0 \mathrm{~mm}\end{array}$ \\
\hline \multirow{3}{*}{ Particle number } & $\begin{array}{l}\text { Initial packing : } \\
\text { Coke: } 5,190,000 \\
\text { Ore }: 3,987,000 \\
\text { Wall particle }: 235,000\end{array}$ \\
\hline & $\begin{array}{l}\text { Coke }: 77,000 \text { per charge } \\
\text { Ore }: 208,000 \text { percharge }\end{array}$ \\
\hline & Maximum particle number: $16,000,000$ (total) \\
\hline Particle density & Coke $: \rho_{p}=1,050 \mathrm{~kg} / \mathrm{m}^{3}$, Ore $: \rho_{\mathrm{p}}=3,260 \mathrm{~kg} / \mathrm{m}^{3}$ \\
\hline Stiffnes coefficient & $\mathrm{E}=5.0 \times 10^{7} \mathrm{~N} / \mathrm{m}^{2}$ \\
\hline Poisson's ratio & $v_{p}=0.25$ \\
\hline Friction coefficient & $\mu_{\mathrm{p}}=0.45$ \\
\hline
\end{tabular}

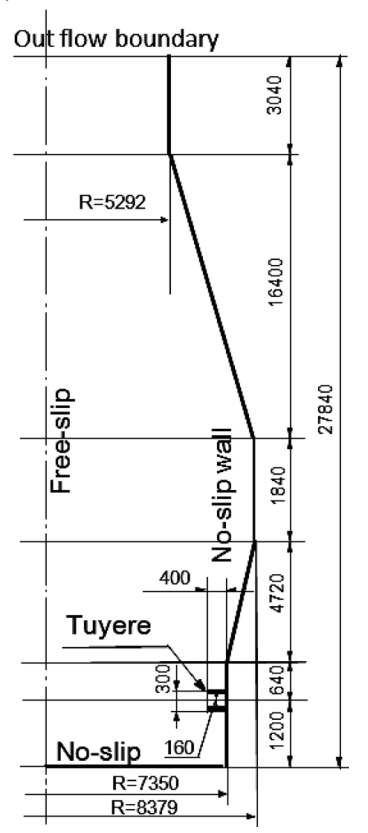

(b)

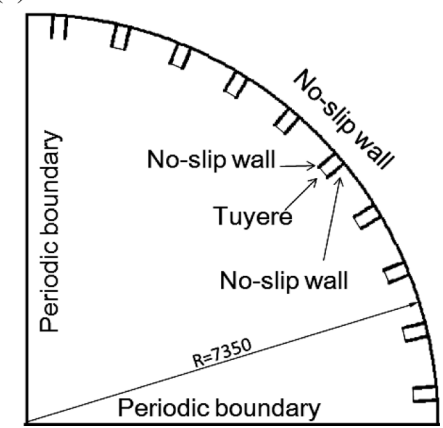

Fig. 1. (a) $R-Z$ plane in computational domain and boundary conditions (unit is $\mathrm{mm}$ ). (b) $\theta$-direction boundary conditions (unit is $\mathrm{mm}$ ).

Table 1. Computational conditions.

coke particles. Therefore we erased the coke particle of which relative velocity between the particle and the air was maximum in the spherical region at an instant in turn during $\Delta T$. The particle number removed per second in the raceway is about $600-1000$ times of a real case. Then we consider approximately that $1 \mathrm{~s}$ in this simulation corresponds to about $600-1000 \mathrm{~s}$ in real phenomena. Table 2 shows the measured initial size distributions of the coke 


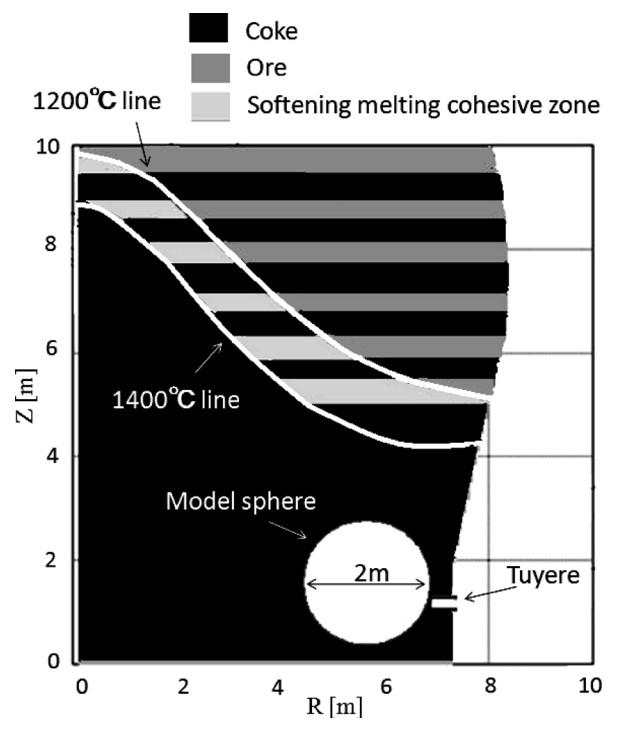

Fig. 2. $1200^{\circ} \mathrm{C}$ and $1400^{\circ} \mathrm{C}$ lines, and model spherical region in which the coke particles are erased.

Table 2. Measured size distribution of coke and iron ore particles used for calculation $(Q$ : number base cumulative under size ratio).

\begin{tabular}{|r|r|r|r|}
\hline \multicolumn{2}{|c|}{ Coke } & \multicolumn{2}{c|}{ Ore } \\
\hline \multicolumn{1}{|c|}{ Dp [mm] } & \multicolumn{1}{|c|}{ Q [-] } & \multicolumn{1}{c|}{ Dp [mm] } & \multicolumn{1}{c|}{ Q [-] } \\
\hline $\mathbf{6 7 . 5}$ & $\mathbf{1 . 0 0 0}$ & $\mathbf{4 9 . 0}$ & $\mathbf{1 . 0 0 0}$ \\
\hline $\mathbf{6 5 . 8}$ & $\mathbf{0 . 9 8 9}$ & $\mathbf{4 8 . 3}$ & $\mathbf{0 . 9 8 8}$ \\
\hline 64.2 & $\mathbf{0 . 9 7 7}$ & $\mathbf{4 7 . 5}$ & $\mathbf{0 . 9 7 8}$ \\
\hline 62.5 & $\mathbf{0 . 9 4 1}$ & $\mathbf{4 6 . 8}$ & $\mathbf{0 . 9 2 0}$ \\
\hline 60.8 & $\mathbf{0 . 8 1 7}$ & $\mathbf{4 6 . 1}$ & $\mathbf{0 . 8 5 0}$ \\
\hline 59.2 & $\mathbf{0 . 6 1 5}$ & $\mathbf{4 5 . 4}$ & $\mathbf{0 . 7 5 2}$ \\
\hline $\mathbf{5 7 . 5}$ & $\mathbf{0 . 4 3 7}$ & $\mathbf{4 4 . 6}$ & $\mathbf{0 . 5 8 4}$ \\
\hline $\mathbf{5 4 . 0}$ & $\mathbf{0 . 6 6 6}$ & $\mathbf{4 3 . 9}$ & $\mathbf{0 . 3 7 9}$ \\
\hline $\mathbf{5 0 . 5}$ & $\mathbf{0 . 1 5 9}$ & $\mathbf{4 3 . 2}$ & $\mathbf{0 . 1 8 8}$ \\
\hline $\mathbf{4 7 . 5}$ & $\mathbf{0 . 1 0 9}$ & $\mathbf{4 2 . 5}$ & $\mathbf{0 . 0 9 1}$ \\
\hline $\mathbf{4 3 . 5}$ & $\mathbf{0 . 0 7 8}$ & $\mathbf{4 1 . 7}$ & $\mathbf{0 . 0 5 5}$ \\
\hline 39.5 & $\mathbf{0 . 0 6 6}$ & $\mathbf{4 1 . 0}$ & $\mathbf{0 . 0 3 0}$ \\
\hline
\end{tabular}

and the iron ore particles which were used in the present simulation.

\subsection{Phase Change of Iron Ore Particles in Melting Zone between $1200^{\circ} \mathrm{C}$ and $1400^{\circ} \mathrm{C}$ Lines}

When the center of the iron ore particle reached at the $1200^{\circ} \mathrm{C}$ line in the blast furnace as shown in Fig. 2, 50\% of the particle volume melted and the diameter $D_{p}$ of the ore particle reduced to $0.794 D_{p}$ by melting the particle surface. The cohesion force by Eq. (11) ${ }^{16)}$ acted between the particles contacted by the melting liquid and the drag force by Eq. $(12)^{17)}$ acted on the particle by the melting liquid around the particle surface. In this model $0.794 D_{p}$ was used for the melted ore particle diameter in DEM calculation. When the center of the melted iron ore particle reached at the $1400^{\circ} \mathrm{C}$ line shown in Fig. 2 in the blast furnace, the residue of the iron ore particle melted down completely. tion.

The void fraction was calculated by the following equa-

$$
\varepsilon=\left(V_{0}-V_{p}-V_{l}\right) / V_{o}
$$

The packing fraction $P_{f}$ is $(1-\varepsilon)$.

We used 16 node processors with 500MFlops of Earth Simulator and the work station (DELL Precision T 7400 (4core, $3.2 \mathrm{GHz}, \mathrm{Xeon} \times 2)$ ) in Earth Simulator Center for the

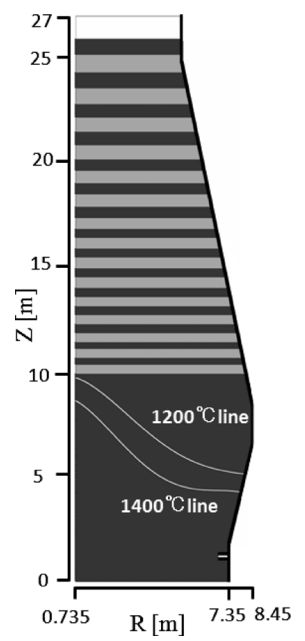

Fig. 3. Initial piles of the coke and iron ore particles.

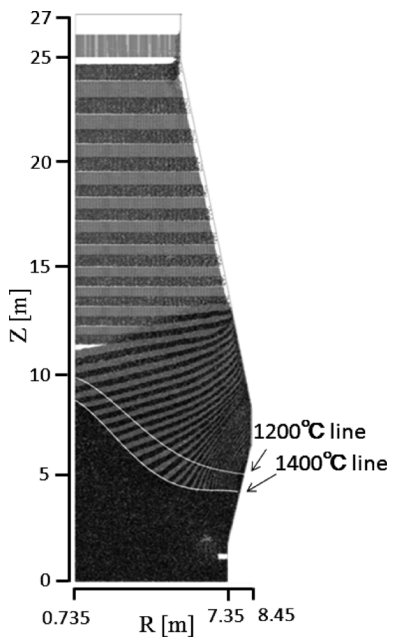

Fig. 4. Calculated instantaneous coke and iron ore particle locations in $R-Z$ plane $\left(\theta=40.5^{\circ}\right)$ at $3.05 \mathrm{~s}$ after the air begins to issue to the blast furnace.

computation. 16 node processors in Earth Simulator and the work station took about 2000 node hours and about $1680 \mathrm{~h}$ for the calculation of about 1 second phenomenon, respectively.

\section{Results and Discussion}

Initially the layers of coke and iron ore particles were alternatively piled regularly in the actual blast furnace as shown in Fig. 3. The black layers are the coke particle layers and the gray layers are the iron ore particle layers in the figures in this study. After that the particles began to settle, namely began to free fall, and simultaneously the air issued from ten tuyeres. The numbers of coke and iron ore particles for one charge to the blast furnace were 77 thousand and 208 thousand respectively. Figure 4 shows the calculated instantaneous particle location in $R-Z$ plane at $3.05 \mathrm{~s}$ after the air begins to issue to the blast furnace. We plotted all of particles existing in one computational cell depth in the figures of the particle location in this study. $3.05 \mathrm{~s}$ corresponds to about $50 \mathrm{~min}$ of the real phenomena, because the erasing speed of the coke particles was about one thousand times of the real speed in the present simulation. Fig- 
ure 4 shows that the moving packed bed of the coke and iron ore particles are formed by the interactions among the particles and the air in the region below the height $Z<11 \mathrm{~m}$ at the center and $Z<13 \mathrm{~m}$ at the wall of the blast furnace. At $T=3.05 \mathrm{~s}$ the particle and the air motions in the region of the moving packed bed are approximately a macroscopic steady state in which the large scale periodic motion and the rapid fluctuation still exist. The both layers of coke and iron ore particles still exist. These layers become thin and descend in the blast furnace. The flow patterns of the coke and the ore particles show the funnel flow which is such that granular material in a hopper is mainly in motion in the central region and there is the large slow motion region near the hopper wall. The funnel flow usually occurs by the interactions among particles and between particles and wall caused by the friction force, shear force and normal force among particles and between particles and wall. Chou and Chen ${ }^{19)}$ present the measured flow patterns, which are similar to the flow patterns of the coke and the ore particles in the blast furnace shown in Fig. 4, of granular material in a hopper. The descending velocity decreases with approaching to the furnace wall because of the effect of the stationary wall. Therefore the layer inclined angle from the horizontal increases with decreasing the distance to the stationary wall due to the effect of the wall. These slopes become nearly vertical in the region near the wall. As mentioned later, the slopes largely affect the air flow in the blast furnace. Since the iron ore particles completely melt on the $1400^{\circ} \mathrm{C}$ line, the iron ore particles do not exist in the region below $1400^{\circ} \mathrm{C}$ line. The free fall by the sedimentation of the coke and the iron ore particles continues in the area $Z>11 \mathrm{~m}$ at the center and $Z>13 \mathrm{~m}$ at the wall in the blast furnace as shown in Fig. 4. Figure 5 shows the calculated instantaneous particle location in $R-\theta$ plane $Z=7.0-7.1 \mathrm{~m}$ at $3.05 \mathrm{~s}$ after the air begins to issue to the blast furnace. The sizes of layers which are initially piled regularly become slightly irregular and the widths decrease with decreasing the distance to the wall. However both layers of coke and iron ore particles still exist and would affect the motions of the air and the solid particles. The central region where $X$ and $Y$ are smaller than about $2.3 \mathrm{~m}$ in this figure is the region below the $1400^{\circ} \mathrm{C}$ line. Since the iron ore particles completely melt on the $1400^{\circ} \mathrm{C}$ line, the iron ore particles do not exist in this region.

Figures 6(a) and 6(b) show the calculated instantaneous particle locations in $R-\theta$ planes $Z=1.05-1.35 \mathrm{~m}$ at $2.65 \mathrm{~s}$ and $Z=1.35-1.65 \mathrm{~m}$ at $2.37 \mathrm{~s}$ after the air begins to issue to the blast furnace. The air flows from ten tuyeres interact with the coke particles and with each other, and form the raceways as shown in Fig. 6(a). The shape and the size are not same to each other, even in the typical case shown in Fig. 6(a). The averaged value of the raceway depth, defined in the Refs. 11) and 20), in Fig. 6(a) is $1.06 \mathrm{~m}$. The averaged experimental raceway depth which was measured in Kobe Steel Ltd., Kakogawa No. 3 blast furnace using micro wave reflection gunned through tuyere by Matsui et $a l^{20)}$ is $1.25 \mathrm{~m}$. Our calculated raceway depth is in fairly good agreement with the measured value by Matsui et al. However the precise remark could not be drown from this comparison because there are differences between Matsui et al.'s experimental conditions and our calculated conditions, for example our coke particle diameter would be 1.5 times larger than that of Matsui et al. and our tuyere diameter is

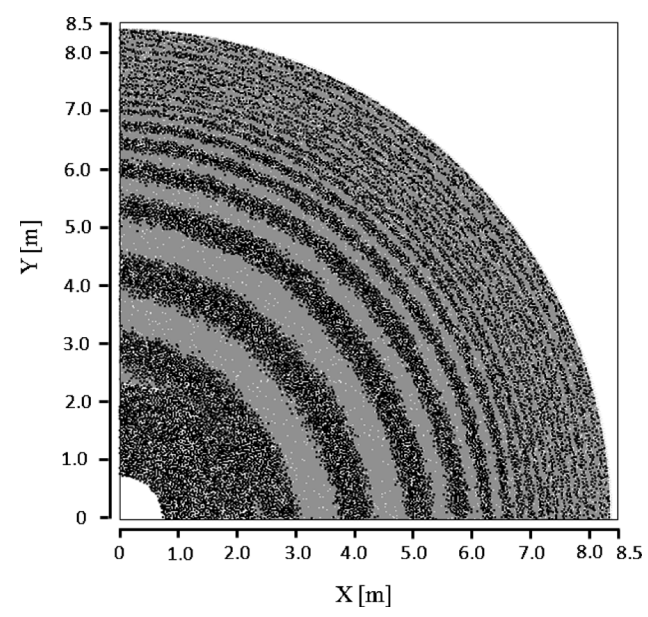

Fig. 5. Calculated instantaneous coke and iron ore particle locations in $R-\theta$ plane $(Z=7.0-7.1 \mathrm{~m})$ at $3.05 \mathrm{~s}$ after the air begins to issue to the blast furnace.

(b)

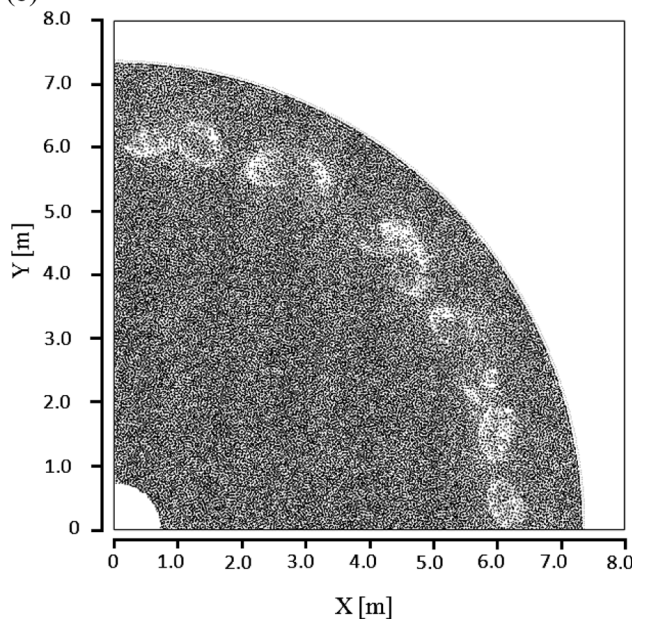

Fig. 6. (a) Calculated instantaneous coke and iron ore particle locations in $R-\theta$ plane $(Z=1.05-1.35 \mathrm{~m})$ at $2.65 \mathrm{~s}$ after the air begins to issue to the blast furnace. (b) Calculated instantaneous coke and iron ore particle locations in $R-\theta$ plane $(Z=1.35-1.65 \mathrm{~m})$ at $2.37 \mathrm{~s}$ after the air begins to issue to the blast furnace. 
about 1.2 times larger. The large coke particle would reduce the raceway depth, on the other hand the large tuyere diameter becomes large the raceway depth. Nevertheless the fairly good agreement between them indicates that the present computational procedure and results would be reasonable. Our calculated results would present the rough but the proper estimation of raceway characteristics. Figure 6(b) shows the raceway which is formed by the interaction of each pair of two flows from tuyeres. The shape and the size of the interacted raceway were unsteady and largely changed. The merging of two raceways shown in Fig. 6(b) would not be a usual case. Our calculated raceway time evolution, omitted here, indicated that many different flow patterns of raceway interacted with the coke particles and with each other existed in the blast furnace. These interacted raceways would cause the unstable flows of the gas and the solid particles in the blast furnace. Figure 7 shows the black and white contour of the calculated packing fraction in $R-Z$ plane at $3.05 \mathrm{~s}$ after the air begins to issue to the blast furnace. The contours in the figures in the present study were drawn using the values averaged in a computational cell. There is a long zone that slopes from the left to the right and ranges from the center to the wall of the blast furnace in Fig. 7. The upper and lower sides of this zone agree with $1200^{\circ} \mathrm{C}$ and $1400^{\circ} \mathrm{C}$ lines respectively. The black stripes between these two lines in the zone are the model softening melting cohesive zones in which the half volume of the iron ore particles melts to the liquid. Since the ore particles and the coke particles entered into the melting liquid and were slightly bonded by the liquid film cohesion force, the volume fraction of the solid particle and the melting liquid to the air in the softening melting cohesive zone increased. The contour of the packing fraction in Fig. 7 shows that the packing fraction including the melting liquid in the softening melting cohesive zone is obviously high and becomes large up to 0.7 , and also the packing fraction in the wide region upper the softening melting cohesive zones gradually increases with descending to these zones in the furnace. The raceway forms in the region in front and upper side of the tuyere. The low packing fraction region including the extremely low packing space in Fig. 7 shows the raceway. The downward movement of the coke particles and the pressure of the air flow from the raceway

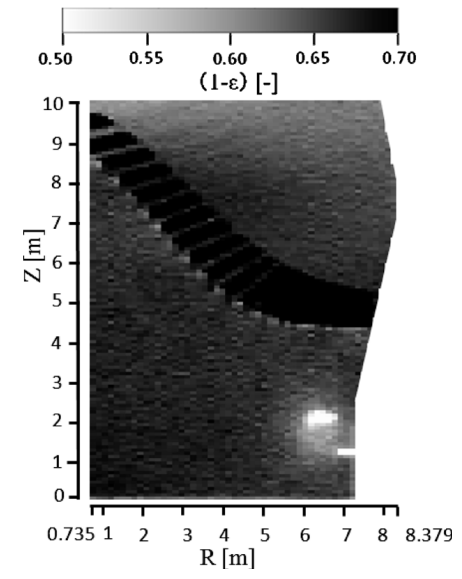

Fig. 7. Calculated instantaneous iso-contour of packing fraction in $R-Z\left(\theta=40.5^{\circ}\right)$ plane at $3.05 \mathrm{~s}$ after the air begins to issue to the blast furnace. make the packing fraction high in the center and the bottom of the blast furnace. Figure 8 shows the black and white contour of the calculated packing fraction in $R-\theta$ plane at $2.65 \mathrm{~s}$ after the air begins to issue to the blast furnace. The region of the extremely low packing fraction shows the raceway. The time evolution of the contours indicated that the raceway grew, collapsed, and was reproduced. The raceway fluctuated by the effect of the mutual interaction of particles and other raceway. This figure also shows that the packing fraction increases with approaching to the furnace center. This high packing fraction would gradually form the dead man. Figure 9 shows the black and white contour of the calculated vertical velocity component of solid particles including both particles of the coke and iron ore in $R-Z$ plane at $3.05 \mathrm{~s}$ after the air begins to issue to the blast furnace. The vertically descending velocity of particles is high in the central region of the zone between $1200^{\circ} \mathrm{C}$ and $1400^{\circ} \mathrm{C}$ lines and the velocity decreases with approaching to the furnace wall. These are because particles can move easily in the melting liquid in the softening melting cohesive zones and on the other hand the furnace wall restrains the particle motions. Figure 9 also shows that the regions of which particle velocities are nearly zero that means solid

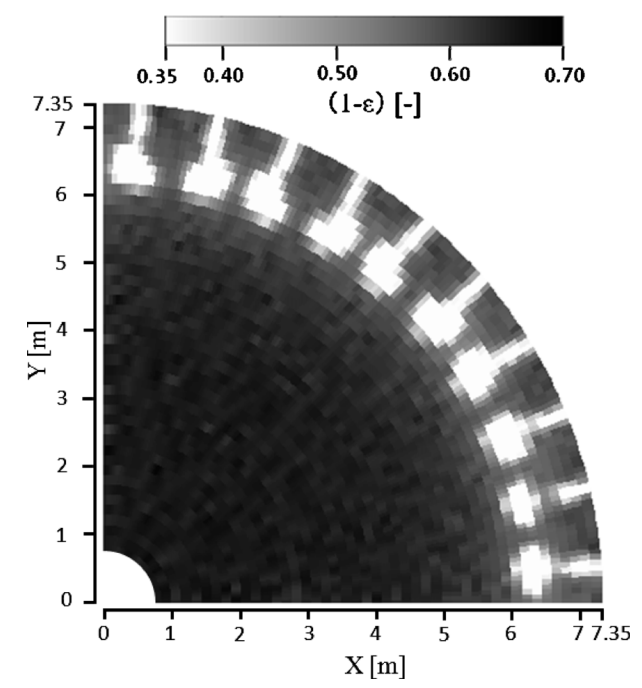

Fig. 8. Calculated instantaneous iso-contour of packing fraction in $R-\theta(Z=1.12-1.20 \mathrm{~m})$ plane at $2.65 \mathrm{~s}$ after the air begins to issue to the blast furnace.

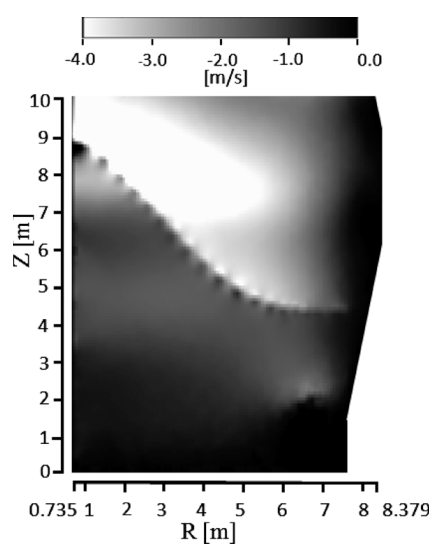

Fig. 9. Calculated instantaneous iso-contour of vertical velocity of coke and iron ore particles in $R-Z$ plane $\left(\theta=40.5^{\circ}\right)$ at $3.05 \mathrm{~s}$ after the air begins to issue to the blast furnace. 


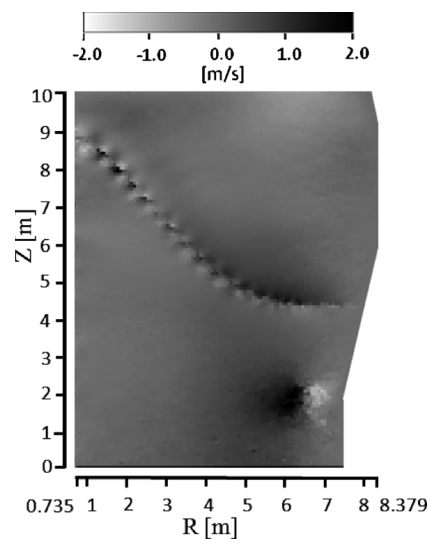

Fig. 10. Calculated instantaneous iso-contour of radial velocity of coke and iron ore particles in $R-Z$ plane $\left(\theta=40.5^{\circ}\right)$ at $3.05 \mathrm{~s}$ after the air begins to issue to the blast furnace.

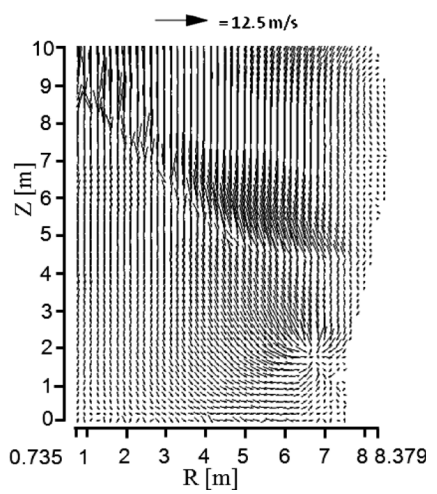

Fig. 11. Calculated instantaneous velocity vectors of coke and iron ore particles in $R-Z$ plane $\left(\theta=40.5^{\circ}\right)$ at $3.05 \mathrm{~s}$ after the air begins to issue to the blast furnace.

particles being almost at rest are formed in the region near the furnace wall including the space just on the wall. These particle layers in the region would cause a scaffold. The time evolution of the contours, omitted here, indicated that the quiescence region of solid particles on the furnace wall grew and collapsed, and was reproduced. The particle flow in the region of the upper part of $1200^{\circ} \mathrm{C}$ line is similar to a granular funnel flow, which is such that the granular material in the central region is mainly in motion and there are large quasi-static regions near the wall, by the effect of the furnace wall. Figure 10 shows the black and white iso-contour of the calculated radial velocity component of solid particles including both particles of the coke and iron ore in $R-Z$ plane at $3.05 \mathrm{~s}$ after the air begins to issue to the blast furnace. The radial velocities of the coke and the ore particles are much smaller than the vertical velocities except those in the raceway. The contours of the positive and the negative radial velocities in the raceway region indicate the particle rotation in that region. The iso-contours in the softening melting cohesive zones show that the radial velocity of solid particles is also larger than that in the other region, because the solid particles easily move in the melting liquid in the softening melting cohesive zone. The direction of the radial velocity of the coke particles alternatively changes to the positive and the negative on the $1400^{\circ} \mathrm{C}$ line because the ore particles completely melt on this line.

Figure 11 shows the instantaneous particle velocity vector diagram in the same plane and at the same instant of

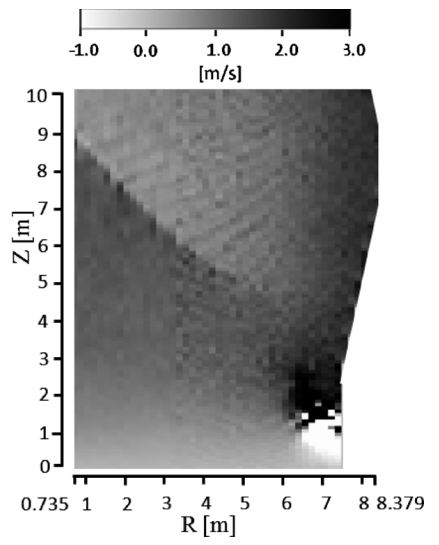

Fig. 12. Calculated instantaneous iso-contour of air vertical velocity in $R-Z$ plane $\left(\theta=40.5^{\circ}\right)$ at $3.05 \mathrm{~s}$ after the air begins to issue to the blast furnace.

Figs. 9 and 10. The calculated particle and air velocities in the figures in this paper are the values averaged in a computational cell. The position of an arrow represented the velocity vector in the figures is a center of computational cell. This figure clearly indicates that the particle velocity changes on the $1400^{\circ} \mathrm{C}$ line on which the iron ore particles completely melt. The disappearance of the ore particles of which vertical velocity is higher than that of coke particles because of their larger particle density and the change of the air velocity direction at the $1400^{\circ} \mathrm{C}$ line as mentioned later would cause the particle velocity change. The whole particles flow to the raceway in the region below the $1400^{\circ} \mathrm{C}$ line. Figures 9,10 and 11 show that the furnace core of which packing fraction was large and velocity was nearly zero was formed in the central region of $Z<3 \mathrm{~m}$. Figure 12 shows the black and white contour of the calculated vertical velocity component of air in $R-Z$ plane at $3.05 \mathrm{~s}$ after the air begins to issue into the blast furnace. The air issues from the tuyere and flows upward. The upward air flow is divided into two streams. One of the streams flows toward the center of the furnace and flows upward, and collides to the softening melting cohesive zones. The collision suddenly changes the direction of the air flow as shown in Fig. 12. The main part of the air flows through the coke zones adjoining the softening melting cohesive zones because the packing fraction in the coke zone is much smaller than that of the softening melting cohesive zones. The narrow stripes with higher vertical air velocity, which are the coke zones adjoining the stripes with lower vertical air velocity which are the softening melting cohesive zones, show this part of the air flow in Fig. 12. Since the flow resistance for the air in the softening melting zone is high owing to the high packing fraction, the air velocity is low as shown by the stripes with lower vertical air velocity in Fig. 12. As mentioned earlier, the angle of the slope from the horizontal of these zones increases with approaching to the wall. These slopes become nearly vertical in the region near the wall as shown in Fig. 4. Therefore the air flows upward through these zones. Thus the other air stream is vertically upward flow along the region near the furnace wall. The air flows upward with comparatively higher velocity mainly through the coke zones. The air upward velocity in the region near the wall including the region in which the particles are almost at rest is not small, 


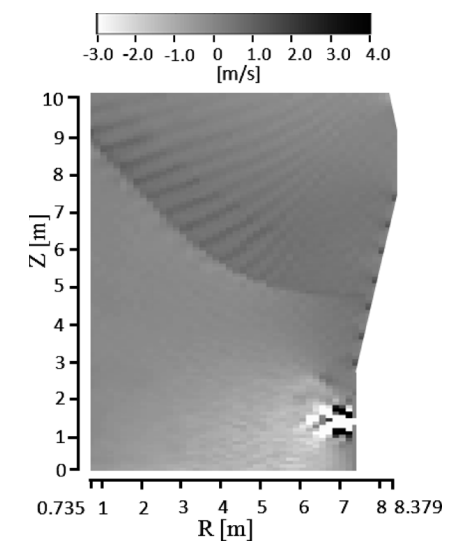

Fig. 13. Calculated instantaneous iso-contour of air radial velocity in $R-Z$ plane $\left(\theta=40.5^{\circ}\right)$ at $3.05 \mathrm{~s}$ after the air begins to issue to the blast furnace.

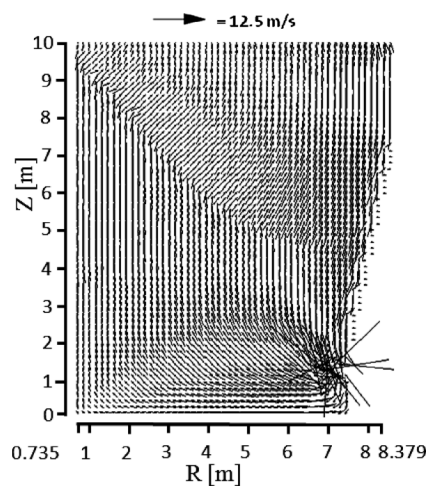

Fig. 14. Calculated instantaneous air velocity vector in $R-Z$ plane $\left(\theta=40.5^{\circ}\right)$ at $3.05 \mathrm{~s}$ after the air begins to issue to the blast furnace.

that is about $1.5 \mathrm{~m} / \mathrm{s}$. The air would flow through around quiescent solid particles even on the wall. The air in the bottom region in the furnace is almost quiescent. Figure 13 shows the black and white contour of the calculated radial velocity component of air in $R-Z$ plane at $3.05 \mathrm{~s}$ after the air begins to issue into the blast furnace. The air stream which collides to the softening melting cohesive zones changes the direction, that is, the air flow direction which is to the furnace center in the region below the softening melting cohesive zones is changed to the furnace wall by the softening melting cohesive zones in which the air hardly flows because the packing fraction in these zones is high. The air mainly flows in the coke zones which are parallel and adjacent to the softening melting zones. Figure 13 shows that the radial velocity of the air in the coke zones between $1200^{\circ} \mathrm{C}$ and $1400^{\circ} \mathrm{C}$ lines is much higher than that in the softening melting cohesive zones. The air radial velocity becomes smaller with approaching the furnace wall. The air radial velocity in the bottom region of the furnace including the furnace core is very low. Figure $\mathbf{1 4}$ shows the velocity vector with the calculated radial and vertical velocity components of the air in $R-Z$ plane at $3.05 \mathrm{~s}$ after the air begins to issue into the blast furnace. This figure clearly indicates that the air flow bifurcates by the softening melting zones existing in the region between $1200^{\circ} \mathrm{C}$ and $1400^{\circ} \mathrm{C}$ lines. The air vertically flows from the raceway region. The main air stream in the central region of the furnace changes the flow direction at $1400^{\circ} \mathrm{C}$ line and flows mostly through the coke zones adjoining the softening melting zones inclined with about 45 degree from the horizontal as shown in Fig. 14. The other air stream near the wall region flows vertically through mainly the coke zones adjacent to the softening melting zones without changing the flow direction, because the coke zones and the softening melting zones become nearly vertical in the region near the furnace wall as shown in Fig. 4. The interaction of the air and the coke particles forms the raceway. The air flow from the raceway pushes the coke particle zone in the bottom and the core regions. This would be one of the reasons which cause the packing fraction in the region to become high and to form the furnace core.

\section{Conclusions}

The following concluding remarks are obtained.

(1) The pattern, the shape and the structure of the model softening melting cohesive zones have been presented using the simple model that $50 \%$ of the ore particle volume melted and the diameter $D_{p}$ reduced to $0.794 D_{p}$ by melting the particle surface at the $1200^{\circ} \mathrm{C}$ line and the residue of the melting iron ore particle melted down completely at the $1400^{\circ} \mathrm{C}$ line.

(2) The packing fraction $P_{f}$ which includes the melting liquid around the melting ore particle in the softening melting cohesive zone becomes high, for example $P_{f}=0.7$. Then it is hard that the air flows into the softening melting cohesive zone.

(3) Since the vertical velocity of the solid particle in the coke and the ore particle zones including the softening melting cohesive zone decreases with approaching to the furnace wall, the slopes of the softening melting zone and other particle zones of which slopes are initially horizontal become nearly vertical in the region near the furnace wall.

(4) The air stream from the raceway region flows upward and collides with the softening melting cohesive zones. After that the air mainly flows in the coke zones adjacent and parallel to the softening melting cohesive zones because it is hard for the air to flow into the softening melting zones with the high flow resistance due to the high packing fraction. Thus the air flow direction which is vertically upward is changed to be parallel to the coke zones adjacent and parallel to the softening melting cohesive zones. Since the slopes of the softening melting cohesive zones and other particle zones are nearly vertical in the region near the furnace wall, the flow direction of the air is not changed in the region near the furnace wall. Therefore the air stream is divided into two streams at the softening melting zones. The one is the flow with the slope angle nearly $45^{\circ}$ from the horizontal toward the furnace wall and the other is vertically upward flow.

(5) The downward velocities of the coke and the ore particles become high in the softening melting cohesive zone because the solid particle easily moves in the melting liquid of the melted ore particles. The downward velocity in the central region of the furnace in which the wall effect is small is higher than that in the region near the wall. The downward velocity of the coke particles with lower particle density is lower than that of the ore particles with higher particle density. The downward velocity of the coke parti- 
cles suddenly becomes low below the $1400^{\circ} \mathrm{C}$ line because the ore particles melt down completely at that line.

(6) The softening melting cohesive zone largely affects the air and the solid particle flows and the existence of the zone becomes the air and the particle flows unsteady and non-homogeneous.

(7) The furnace core of which packing fraction was large and velocity was nearly zero was formed in the central region of $Z<3 \mathrm{~m}$ for about $5000 \mathrm{~m}^{3}$ blast furnace.

(8) The quiescent particle layers were formed on the furnace wall. These layers grow up and collapse at some critical size, and are reproduced. These layers would cause a scaffold.

\section{Acknowledgement}

We would like to thank Japan Agency for Marine-Earth Science and Technology for providing Earth Simulator and the work station to our numerical simulation. We would also like to thank Dr. Y. Hirokawa and Dr. H. Uehara for their useful advices and discussions to the optimization of our computational program.

\section{Nomenclature}

$C_{L}:$ Lift coefficient $(-)$

$D$ : Radius of blast furnace at tuyere section (m)

$\mathbf{D}_{\mathrm{ij}}$ : Damping force vector at contact point $j$ on $i$ particle $(\mathrm{N})$

$D_{p}:$ Particle diameter $(\mathrm{m})$

$D_{t}:$ Tuyere diameter $(\mathrm{m})$

$d$ : Solid core diameter of iron ore particle in softening melting cohesive zone $\left(=0.794 D_{p}\right)(\mathrm{m})$

$E$ : Modulus of elasticity $\left(\mathrm{N} \mathrm{m}^{-2}\right)$

$\mathbf{F}_{\mathrm{ij}}$ : Elastic force vector at contact point $j$ on particle $i$ (N)

$\mathbf{F}_{\mathbf{C i}}$ : Resultant force vector of $F_{C}$ acting on particle $i$ (N)

$F_{C}$ : Cohesion force due to liquid bridge between particles in softening melting cohesive zone $(\mathrm{N})$

$F_{D i}$ : Fluid drag force acting on particle $i(\mathrm{~N})$

$F_{L i}$ : $\quad$ Fluid lift force acting on particle $i(\mathrm{~N})$

$\mathbf{F}_{\mathrm{Gi}}$ : Gravitational force vector acting on particle $i(\mathrm{~N})$

$\mathbf{F}_{\mathbf{R i}}$ : Resultant force vector of $F_{R}$ acting on particle $i$ (N)

$F_{R}$ : Drag force acting on approaching particles with liquid film in softening melting cohesive zone $(\mathrm{N})$

$I_{p}: \quad$ Inertia moment of particle $\left(\mathrm{kg} \mathrm{m}^{2}\right)$

$L$ : Minimum separation between particles (m)

$M$ : Parameter of fluid friction torque $(\mathrm{Nm})$

$\mathbf{M}_{\mathrm{ij}}$ : Moment vector due to elastic force at contact point $j$ on particle $i(\mathrm{Nm})$

$\mathbf{M}_{\mathbf{D}_{\mathbf{i j}}}$ : Moment vector due to damping force at contact point $j$ on particle $i(\mathrm{Nm})$

$\mathbf{M}_{\mathbf{F}_{\mathrm{i}}}$ : Fluid friction torque vector acting on particle $i$ (Nm)

$m_{p}: \quad$ Particle mass $(\mathrm{kg})$

$N$ : Number of particles per unit volume (-)

$n$ : Term number of series solution $\beta(-)$

$p:$ Nondimensional static pressure $(-)$

$P_{f}$ : Packing fraction $(-)$

$R_{1}$ : Curvature radius of liquid bridge $(=[d(1-\cos \alpha)+L] /[2 \cos (\alpha+\Theta)])(\mathrm{m})$
$R_{2}$ : Dimension of liquid bridge $\left(=(d / 2) \sin \alpha+R_{1}[\sin (\alpha+\Theta)-1]\right)(\mathrm{m})$

Re: Reynolds number $\left(=D U_{o} / v\right)(-)$

$\mathrm{Re}_{p}$ : Particle Reynolds number $\left(=D_{p}\left|\mathbf{U}-\mathbf{U}_{p}\right| / v\right)(-)$

$\mathrm{Re}_{p \omega}$ : Particle Reynolds number based on rotation $\left(=\left|(1 / 2) \nabla \times \mathbf{U}-\Omega_{p}\right| D_{p}{ }^{2} /(4 v)\right)(-)$

St : Nondimensional interaction term due to fluid drag force $(-)$

$\mathbf{S t}_{\mathbf{L}}$ : Nondimensional interaction term due to fluid lift force $(-)$

$T:$ Time (s)

$t:$ Nondimensional time $(-)$

$\mathbf{U}:$ Air velocity vector $\left(\mathrm{m} \mathrm{s}^{-1}\right)$

u : Nondimensional air velocity vector (-)

$\mathbf{U}_{\mathbf{p}}$ : Particle velocity vector $\left(\mathrm{m} \mathrm{s}^{-1}\right)$

$\mathbf{u}_{\mathbf{p}}$ : Nondeminsional particle velocity vector $(-)$

$u_{p n}$ : Normal component of relative velocity vector between particles $\left(\mathrm{m} \mathrm{s}^{-1}\right)$

$U_{0}:$ Air velocity at the tuyere outlet $\left(\mathrm{m} \mathrm{s}^{-1}\right)$

$V_{o}$ : Nondimensional volume of computational cell $(-)$

$V_{l}$ : Nondimensional volume of melted liquid in $V_{o}$ $(-)$

$V_{p}$ : Nondimensional volume of particles in $V_{o}(-)$

$r, \theta, z:$ Cylindrical coordinates $(-)$

$x, y, z:$ Cartesian coordinates $(-)$

Greek

$\alpha$ : Contact angle of liquid film (rad)

$\varepsilon$ : Void fraction $(-)$

$\gamma:$ Surface tension of liquid film $\left(\mathrm{N} \mathrm{m}^{-1}\right)$

$\mu: \quad$ Air viscosity (Pa s)

$\mu_{l}: \quad$ Viscosity of liquid film ( $\mathrm{Pas}$ )

$\mu_{p}$ : Friction coefficient between particles $(-)$

$v$ : Kinematic viscosity $\left(\mathrm{m}^{2} \mathrm{~s}^{-1}\right)$

$v_{p}:$ Poisson's ratio $(-)$

$\Theta: \quad$ Coverage angle of liquid film on particle (rad)

$\xi(\varepsilon), \xi_{L}(\varepsilon)$ : Correction functions of drag and lift forces in multi-particle system (-)

$\rho: \quad$ Air density $\left(\mathrm{kg} \mathrm{m}^{-3}\right)$

$\rho_{p}$ : Particle density $\left(\mathrm{kg} \mathrm{m}^{-3}\right)$

$\Omega_{\mathrm{pi}}$ : Particle angular velocity vector $\left(\mathrm{rad}^{-1}\right)$

$\Omega^{*}$ : Velocity ratio of rotation and translation $(-)$

$\omega_{\mathbf{p}}$ : Nondimensional particle angular velocity vector $(-)$

$\nabla: \quad$ Nondimensional nabla operator $(-)$

\section{REFERENCES}

1) H. Yamaoka and K. Nakano: Science and Technology-Promotion of Scientific Research, Interim Report 2001, MEXT, (2001), 1.

2) B. H. Xu, A. B. Yu, S. J. Chew and P. Zulli: J. Soc. Powder Technol., 109 (2000), 13

3) S. J. Zhang, A. B. Yu, P. Zulli, B. Wright and P. Austin: Appl. Math. Model., 26 (2002), 141.

4) H. Takahashi, H. Kawai and Y. Suzuki: Chem. Eng. Sci., 57 (2002), 215.

5) J. K. Walters: Chem. Eng. Sci. A, 28 (1973), 13.

6) J. K. Walters: Chem. Eng. Sci. B, 28 (1973), 779.

7) T. Nouchi, A. B. Yu and K. Takeda: J. Soc. Powder Technol., 134 (2003), 98 .

8) H. Nogami, H. Yamaoka and K. Takatani: ISIJ Int., 44 (2004), 2150.

9) L. Schiller and A. Naumann: Z. Ver. Dtsch. Ing., 77 (1933), 318.

10) T. Umekage and S. Yuu: Trans. Jpn. Soc. Mech. Eng. B, 65 (1999), 
ISIJ International, Vol. 50 (2010), No. 7

1392.

11) S. Yuu, T. Umekage and T. Miyahara: ISIJ Int., 45 (2005), 1406.

12) R. Kurose and S. Komori: J. Fluid Mech., 384 (1999), 183.

13) F. H. Harlow and J. E. Welch: Phys. Fluids, 8 (1965), 2182.

14) S. Yuu, T. Umekage and Y. Johno: Powder Technol., 110 (2000), 158.

15) H. Hertz: Gesammelte Werke, 1 (1895), 155.

16) Soc. Powder Technol. Japan Ed.: Powder Technology Handbook, 2nd ed., Nikkan Kogyo Shimbun, Tokyo, Japan, (1998), 69.

17) J. Happel and H. Brenner: Low Reynolds Number Hydrodynamics, Noordhoff Int. Publishing, Leyden, Netherland, (1973), 235.

18) H. Takagi: J. Phys. Soc. Jpn., 42 (1977), 319.

19) C. S. Chou and R. Y. Chen: Adv. Powder Technol., 14 (2003), 195.

20) Y. Matsui, M. Tanaka, M. Sawayama, S. Kitano, T. Imai and A. Goto: ISIJ Int., 49 (2009), 1445. 